\title{
Mitochondrial DNA single nucleotide polymorphism associated with weight estimated breeding values in Nelore cattle (Bos indicus)
}

\author{
Fernando Henrique Biase ${ }^{1}$, Flávio Vieira Meirelles ${ }^{2}$, Ricardo Gunski ${ }^{3}$, Pedro Alejandro Vozzi ${ }^{1}$, \\ Luiz A.F. Bezerra ${ }^{1}$, Reginaldo A. Vila ${ }^{1}$, Artur J.M. Rosa ${ }^{4}$, Raysildo B. Lôbo ${ }^{1}$ and Lúcia Martelli ${ }^{1}$ \\ ${ }^{1}$ Departamento de Genética, Faculdade de Medicina de Ribeirão Preto, Universidade de São Paulo, \\ Ribeirão Preto, São Paulo, Brazil. \\ ${ }^{2}$ Departamento de Ciências Básicas, Faculdade de Zootecnia e Engenharia de Alimentos, \\ Universidade de São Paulo, Pirassununga, São Paulo, Brazil. \\ ${ }^{3}$ Centro de Ciências Rurais de São Gabriel, Universidade Federal do Pampa, São Gabriel, RS, Brazil. \\ ${ }^{4}$ Department of Animal and Range Sciences, South Dakota State University, Brookings, South Dakota, \\ United States of America.
}

\begin{abstract}
We sampled 119 Nelore cattle (Bos indicus), 69 harboring B. indicus mtDNA plus 50 carrying Bos taurus mtDNA, to estimate the frequencies of putative mtDNA single nucleotide polymorphisms (SNPs) and investigate their association with Nelore weight and scrotal circumference estimated breeding values (EBVs). The PCR restriction fragment length polymorphism (PCR-RFLP) method was used to detect polymorphisms in the mitochondrial asparagine, cysteine, glycine, leucine and proline transporter RNA (tRNA) genes ( $t R N A^{a s n}, t R N A^{c y s}, t R N A^{g l y}, t R N A^{\text {lou }}$ and $t R N A^{p r o}$ ). The 50 cattle carrying $B$. taurus mtDNA were monomorphic for all the tRNA gene SNPs analyzed, suggesting that they are specific to mtDNA from $B$. indicus cattle. No $t R N A^{c y s}$ or $t R N A^{g / y}$ polymorphisms were detected in any of the cattle but we did detect polymorphic SNPs in the $t R N A^{\text {asn }}, t R N A^{\text {tou }}$ and $t R N A^{\text {pro }}$ genes in the cattle harboring $B$. indicus mtDNA, with the same allele observed in the $B$. taurus sequence being present in the following percentage of cattle harboring $B$. indicus mtDNA: $72.46 \%$ for $t R N A^{\text {asn }}, 95.23 \%$ for $t R N A^{\text {teu }}$ and $90.62 \%$ for $t R N A^{\text {pro }}$. Analyses of variance using the $t R N A^{\text {asn }}$ SNP as the independent variable and EBVs as the dependent variable showed that the G $\rightarrow$ T SNP was significantly associated $(p<0.05)$ with maternal EBVs for weight at 120 and 210 days $(p<0.05)$ and animal's EBVs for weight at 210, 365 and 455 days. There was no association of the $t R N A^{\text {asn }}$ SNP with the scrotal circumference EBVs. These results confirm that mtDNA can affect weight and that mtDNA polymorphisms can be a source of genetic variation for quantitative traits.
\end{abstract}

Key words: bovine, mitochondria, mtDNA, SNP, weight.

Received: August 15, 2006; Accepted: March 8, 2007.

\section{Introduction}

Mitochondria are eukaryotic cell organelles involved in various cellular functions, including cell proliferation, apoptosis and, mostly important, energy production (Birch-Machin, 2006) by oxidative phosphorylation (Taanman, 1999). These organelles are responsible for approximately $90 \%$ of the energy produced by the mammal cell (Boettcher et al., 1996b). Mitochondria have their own genome, which is maternally inherited in mammals and is an important source of cytoplasmic genetic variation (Gib-

Send correspondence to Lúcia Martelli. Departamento de Genética, Faculdade de Medicina de Ribeirão Preto, Universidade de São Paulo, Avenida Bandeirantes 3900, 14049-900 Ribeirão Preto, São Paulo, Brazil. E-mail: Irmartel@genbov.fmrp.usp.br. son et al., 1997; Birky, 2001). In cattle, direct maternal effects have been discussed since Wagner (1972) but the contribution of cytoplasmic effects estimated for growth and milk production are not consistent between populations (Gibson et al., 1997).

Boettcher et al. (1996b) demonstrated bias in the heritability, permanent environmental variance, and accuracy estimation in the animal model when the cytoplasmic effects were ignored. Moreover, the effect of cytoplasmic inheritance has been studied in respect to milk production (Bell et al., 1985; Tess et al., 1987; Schutz et al., 1992; Boettcher et al., 1996a) and beef cattle growth traits (Tess and Robison, 1990; Northcutt et al., 1991; Tess and MacNeil, 1994; Quintanilla et al., 1999). 
Recently, molecular biology has furthered our understanding of the function and inheritance of the mitochondrial genome and its importance on livestock development and production (Smith and Alcivar, 1993; Smith et al., 2000). Since Anderson et al. (1982) published the complete mitochondrial DNA (mtDNA) sequence, nucleotide variants in coding and non-coding regions have been studied to associate molecular markers with the production of Bos taurus breeds (Ron et al., 1993; Suzuki et al., 1993; Mannen et al., 1998; Mannen et al., 2003). Pegoraro et al. (1996) identified sequence alterations in mitochondrial transfer RNA (tRNA) genes and in the origin of light strand (Ori L) replication of Bos indicus Nelore cattle as compared to $B$. taurus and described a single nucleotide polymorphism in the Nelore Ori L region and asparagine tRNA $\left(t R N A^{a s n}\right)$ gene. The polymorphisms were later confirmed by the complete genomic sequence of the $B$. indicus mitochondrial DNA (mtDNA) and deposited in the GenBank under accession number AY126697.

Meirelles et al. (1999) reported the existence of cattle carrying the $B$. taurus or $B$. indicus mitochondrial genome in Brazilian Nelore cattle. These animals, with same breed composition but harboring different mitochondrial genomes, constitute an interesting model to investigate the influence of mtDNA polymorphisms on quantitative traits. During the work described in the present paper we tested the hypothesis that cattle with different specific nucleotide variations differ in estimated breeding values (EBVs) for growth and reproductive traits. The aims of this study were to estimate the frequency of single nucleotide polymorphisms of the mitochondrial genes for asparagine tRNA $\left(t R N A^{a s n}\right)$, cysteine tRNA $\left(t R N A^{\text {cys }}\right)$ (Pegoraro et al., 1996), glycine tRNA $\left(t R N A^{g l y}\right)$, leucine tRNA $\left(t R N A^{\text {leu }}\right)$ and proline tRNA $\left(t R N A^{\text {pro }}\right)$ in B. indicus and B. taurus mtDNA from public GenBank sequences AY126697 and AY526085 in Brazilian Nelore cattle and to investigate the effects of these polymorphisms on weight and scrotal circumference estimated breeding values at different ages.

\section{Material and Methods}

\section{Cattle sample}

The sample $(n=119)$ consisted of 69 purebred adult Nelore cattle registered as pure origin imported (POI) in the Brazilian Association of Zebu Breeder's Herdbook and identified as carriers of $B$. indicus mtDNA plus a further 50 purebred $B$. indicus Nelore cattle which were carriers of $B$. taurus mtDNA and not registered as POI. A blood sample was collected from each animal and total DNA extracted according to Sambrook et al. (2001). The presence of $B$. indicus and B. taurus mtDNA was confirmed by the polymerase chain reaction restriction fragment length polymorphism (PCR-RFLP) method by the absence (B. indicus) or the presence (B. taurus) of HindIII restriction site at nucleotide 12178 on the NADH dehydrogenase subunit 5 gene (Meirelles et al., 1999).

\section{Detection of polymorphisms}

The single nucleotide substitutions (SNP) in five transfer RNA (tRNA) mitochondrial genes were detected by PCR-RFLP using endonuclease enzymatic digestion of the amplicons. Primers were designed using the $B$. indicus mtDNA sequence as a reference (GenBank AY126697). The PCR was performed using $150 \mathrm{ng}$ of total DNA, $1 \mathrm{x}$ PCR buffer ( $20 \mathrm{mM}$ Tris- $\mathrm{HCl}, 50 \mathrm{mM} \mathrm{KCl}$, Invitrogen, Brazil), $3 \mathrm{mM} \mathrm{MgCl} 2,0.2 \mathrm{mM}$ of each dNTP, $0.2 \mu \mathrm{M}$ of each primer (Table 1) and 1.5 units of Taq DNA polymerase (Invitrogen, Brazil) in a final volume of $50 \mu \mathrm{L}$. Cycling was set for $5 \mathrm{~min}$ at $95^{\circ} \mathrm{C}$ followed by 35 cycles of $40 \mathrm{~s}$ at $95^{\circ} \mathrm{C}, 30 \mathrm{~s}$ at the specific temperature of each primer and $40 \mathrm{~s}$ at $72{ }^{\circ} \mathrm{C}$, with a final $72{ }^{\circ} \mathrm{C}$ extension for $5 \mathrm{~min}$. The PCR products $(15 \mu \mathrm{L})$ were digested with 1 unit of $B s r \mathrm{I}$, $M n l$ I, Spe I, Dra I or Bsm AI restriction endonuclease specific for each tRNA gene sequence for one hour at the temperature recommended by the supplier (New England Biolabs, USA). The mitochondrial tRNA PCR amplicons, specific primer sequences, annealing temperatures, SNP positions and restriction enzymes used in this study are pre-

Table 1 - Gene names, primers, annealing temperatures (AT), polymerase chain reaction (PCR) amplicon (AP) sizes in base pairs (bp), single nucleotide polymorphism (SNP) base position and restriction enzymes (RE) used in the study. The SNP position indicates the difference between the cut Bos taurus sequence (GenBank AY526085) and the uncut Bos indicus sequence (GenBank: AY126697).

\begin{tabular}{|c|c|c|c|c|c|}
\hline tRNA gene & Primer sequence $\left(5^{\prime}-3^{\prime}\right)$ & $\mathrm{AT}\left({ }^{\circ} \mathrm{C}\right)$ & $\mathrm{AP}(\mathrm{bp})$ & SNP position & RE \\
\hline Asparagine $\left(t R N A^{a s n}\right)$ & $\begin{array}{l}\text { TCCTCACTAGACTGGTGG } \\
\text { GGTTGAGAATAGTCAGCG }\end{array}$ & 52 & 277 & $\mathrm{G} 5501 \rightarrow \mathrm{T}$ & $B s r \mathrm{I}$ \\
\hline Cysteine $\left(t R N A^{c y s}\right)$ & $\begin{array}{l}\text { AGCTAACTGGCTTCAATC } \\
\text { ACCAAATAGTAGATAAAGG }\end{array}$ & 50 & 257 & $\mathrm{C} 5612 \rightarrow \mathrm{T}$ & $M n l \mathrm{I}$ \\
\hline Glycine $\left(t R N A^{g l y}\right)$ & $\begin{array}{l}\text { ACGTCATCATTGGGTCCAC } \\
\text { GAATGCGATGATGACGAGTAG }\end{array}$ & 55 & 300 & $\mathrm{~T} 9768 \rightarrow \mathrm{C}$ & Spe I \\
\hline Leucine $\left(t R N A^{\text {leu }}\right)$ & $\begin{array}{l}\text { AGAAGCCCGGTAATTGCTTTA } \\
\text { ACCTACGACATTTGGACC }\end{array}$ & 52 & 189 & $\mathrm{~A} 3051 \rightarrow \mathrm{G}$ & Dra I \\
\hline Proline $\left(t R N A^{p r o}\right)$ & $\begin{array}{l}\text { GACAGGTCTTTGTAGTACTC } \\
\text { GTAGGTAATTCATTCTGTGG }\end{array}$ & 55 & 302 & $\mathrm{~T} 15751 \rightarrow \mathrm{C}$ & Bsm AI \\
\hline
\end{tabular}


sented in Table 1. Electrophoresis was carried out on $2 \%$ $(w / v)$ agarose gel and DNA was stained with ethidium bromide and the fragments visualized under ultraviolet light. Mitochondrial transfer RNA SNP frequencies were obtained by direct counting of the PCR-RFLP results.

\section{Estimated breeding values}

The cattle selected for mtDNA genotyping were part of the Nelore cattle breeding program (NCBP) at the University of São Paulo (ANCP, http://www.ancp.org.br/ sumarios) which estimated breeding values for approximately 900,000 cattle. The estimated breeding values used in this study for association analysis were kindly provided by the NCBP.

The traits analyzed were maternal effects for weight (MW) at 120 and 210 days $\left(\mathrm{MW}_{120}\right.$ and $\mathrm{MW}_{210}$ ), animal weight (AW) at 120, 210, 365, and 450 days $\left(\mathrm{AW}_{120}\right.$, $\mathrm{AW}_{210}, \mathrm{AW}_{365}$, and $\mathrm{AW}_{450}$ ) and scrotal circumference (SC) at 365,450 , and 550 days $\left(\mathrm{SC}_{365}, \mathrm{SC}_{450}\right.$, and $\left.\mathrm{SC}_{550}\right)$.

Briefly, breeding values for each animal were estimated using an animal model applying the best linear unbiased predictor (Boldman et al., 1995). The model used for genetic parameter estimations was $y=X \beta+Z 1 a+Z 2 m+$ $Z 3 p+e$, where $y$ is a $\mathrm{N} \times 1$ vector of records, $\beta$ the vector of fixed effects (herd-year-season, sex, dam age class), $X$ is the matrix associating $\beta$ with $y, a$ is the vector of estimated breeding values for direct genetic effects, $Z 1$ is the matrix associating $a$ with $y, m$ is the vector of estimated breeding values for maternal genetic effects, $Z 2$ is the matrix associating $m$ with $y, p$ is the vector of permanent environmental non-additive genetic effects contributed by dams to the records of their progeny, $Z 3$ is the matrix associating $p$ with $y$ and $e$ is the vector of residual effects (Gunski et al., 2001).

\section{Association analysis}

Maternal and animal estimated breeding values were independently compared between animals with and without the $B s r$ I restriction site (G or T nucleotide) on the $t R N A^{a s n}$ gene by analysis of variance (ANOVA). The linear model used was: $\mathrm{y}_{\mathrm{ij}}=\mu+\mathrm{N}_{\mathrm{i}}+\mathrm{e}_{\mathrm{ij}}$, where $y_{i j}$ is the breeding value for each trait of the ij ${ }^{\text {th }}$ animal, $N$ is the fixed effect of the $\mathrm{i}^{\text {th }}$ tRNA $^{\text {asn }}$ nucleotide ( $\mathrm{G}$ or T) and $e_{i j}$ is the random error effect associated with the $\mathrm{ij}^{\text {th }}$ observation. Means were compared using the Tukey Studentized Range Test in the SAS program (SAS Institute Inc., 2001). Differences with $\alpha<0.05$ were considered statistically significant.

Nelore Heard-book genealogy data incorporated in the breeding value estimations allowed us to obtain the estimated breeding values for all parents and relatives from each genotyped animal. However, only those ascending the animals harboring $B$. indicus mtDNA were considered for further analysis. Because mitochondrial DNA is inherited maternally, females and their offspring from the same matrilineal lineage were assumed to have the same mitochondrial $t R N A^{a s n}$ nucleotide at position 5501. This allowed us to group females from the same lineage with previously genotyped animals. The new data set was based on $345 \mathrm{ob}-$ servations for each characteristic analyzed and was used for ANOVA and the Tukey test.

\section{Results and Discussion}

All the cattle genotyped showed no sign of heteroplasmy for the five single nucleotide polymorphisms (SNPs) analyzed, suggesting maternal inheritance and homoplasmic distribution within tissues (Attardi, 1985; Smith et al., 2000;Birky, 2001). The 50 cattle genotyped as carrying $B$. taurus mtDNA were monomorphic for the five mitochondrial tRNA gene SNPs analyzed in this study, suggesting that the SNPs evaluated are specific to mtDNA from $B$. indicus cattle.

In this Nelore sample $(\mathrm{n}=119)$ no mitochondrial $t R N A^{c y s}$ or $t R N A^{g l y}$ mutations were found using PCR-RFLP. However, we did detect polymorphic SNPs in the $t R N A^{a s n}$, $t R N A^{l e u}$ and $t R N A^{p r o}$ mitochondrial genes of the cattle harboring $B$. indicus mtDNA $(\mathrm{n}=69)$ where the $B$. taurus sequence (Anderson et al., 1982) was present in $72.46 \%$ of animals for $t R N A^{a s n}, 95.23 \%$ for $t R N A^{l e u}$ and $90.62 \%$ for $t R N A^{p r o}$, the remaining animals having a variant tRNA pattern similar to the $B$. indicus mtDNA GenBank sequence AY126697. Tracing the matrilineal genealogy, we found that each of the 19 cattle genotyped as having B. indicus $t R N A^{a s n}$ were descendants of different females imported from India, suggesting that the nucleotide mutations in the $t R N A^{a s n}, t R N A^{\text {leu }}$ and $t R N A^{p r o}$ mitochondrial genes, characteristic of $B$. indicus cattle, occurred in India and were brought to Brazil with imported Indian cows.

Because the mitochondrial $t R N A^{c y s}$ and $t R N A^{g l y}$ genes were not polymorphic for the SNPs tested in our sample and the mitochondrial $t R N A^{l e u}$, and $t R N A^{p r o}$ genes lacked sufficient variability, we used the SNP on the $t R N A^{a s n}$ gene to compare the estimated breeding values of the cattle harboring $B$. indicus mtDNA in our sample.

As stated above, maternal and animal estimated breeding values were independently compared between the cattle in our sample which had, or lacked, the Bsr I restriction site ( $\mathrm{G}$ or $\mathrm{T}$ nucleotide). The guanidine to thymine substitution was significantly associated $(p<0.05)$ with changes in maternal breeding value for weight at 120 and 210 days and the animal breeding value for weight at 210 , 365 and 455 days (Table 2). Cattle with the mitochondrial $t R N A^{a s n}$ guanidine SNP had higher estimated breeding values compared to those with the thymine SNP (Table 3), although there were no differences for the scrotal circumference estimated breeding values between cattle with different nucleotides at this position (Tables 4 and 5).

Gunski et al. (2001) studied mitochondrial genome effects to compare pre-weaning growth traits between were in Nelore cattle harboring $B$. taurus $\mathrm{mtDNA}$ and $B$. indicus mtDNA, but found no significant $(\mathrm{p}>0.05)$ differences for maternal and animal estimated breeding values. 
Table 2 - Analysis of variance between weight estimated breeding values (EBV) for the G5501 $\rightarrow \mathrm{T}(\mathrm{G}, \mathrm{n}=247 ; \mathrm{T}, \mathrm{n}=71)$ mitochondrial $t R N A^{\text {asn }}$ gene single nucleotide polymorphism (SNP). The table shows degrees of freedom (DF) and the mean square values for maternal EBV for weight (MW) at 120 and 210 days and animal EBV for weight (AW) at 120, 210, 365 and 450 days.

\begin{tabular}{|c|c|c|c|c|c|c|c|}
\hline \multirow[b]{2}{*}{ Source } & \multirow[b]{2}{*}{$\mathrm{DF}$} & \multicolumn{6}{|c|}{ Estimated breeding values (mean squares) } \\
\hline & & $\mathrm{MW}_{120}$ & $\mathrm{MW}_{210}$ & $\mathrm{AW}_{120}$ & $\mathrm{AW}_{210}$ & $\mathrm{AW}_{365}$ & $\mathrm{AW}_{450}$ \\
\hline Genotype & 1 & 57.71 & 68.16 & 14.46 & 146.02 & 757.27 & 884.01 \\
\hline Error & 343 & 6.11 & 10.50 & 15.96 & 37.65 & 102.06 & 132.39 \\
\hline $\operatorname{Pr}>F$ & & 0.00 & 0.01 & 0.34 & 0.04 & 0.00 & 0.01 \\
\hline
\end{tabular}

Table 3 - Weight estimated breeding values (EBV) for the $\mathrm{G} 5501 \rightarrow \mathrm{T}(\mathrm{G}, \mathrm{n}=247 ; \mathrm{T}, \mathrm{n}=71)$ mitochondrial $t R N A^{\text {asn }}$ gene single nucleotide polymorphism (SNP). The table shows the means and standard errors of the mean (SE) for maternal EBV for weight (MW) at 120 and 240 days and animal EBV for weight (AW) at 120, 240, 365 and 450 days.

\begin{tabular}{lcccccc}
\hline & \multicolumn{5}{c}{ Weight estimated breeding values (means $\pm \mathrm{SE}, \mathrm{kg})$} \\
\cline { 2 - 6 }$t R N A^{\text {asn }}$ & $\mathrm{MW}_{120}$ & $\mathrm{MW}_{240}$ & $\mathrm{AW}_{120}$ & $\mathrm{AW}_{240}$ & $\mathrm{AW}_{365}$ & $\mathrm{AW}_{450}$ \\
\hline $\mathrm{G}$ & $1.59 \pm 0.15^{\mathrm{a}}$ & $2.40 \pm 0.19^{\mathrm{a}}$ & $-0.06 \pm 0.25^{\mathrm{a}}$ & $-0.87 \pm 0.38^{\mathrm{a}}$ & $2.86 \pm 0.62^{\mathrm{a}}$ & $1.12 \pm 0.68^{\mathrm{a}}$ \\
$\mathrm{T}$ & $0.58 \pm 0.28^{\mathrm{b}}$ & $1.30 \pm 0.37^{\mathrm{b}}$ & $-0.57 \pm 0.38^{\mathrm{a}}$ & $-2.48 \pm 0.65^{\mathrm{b}}$ & $-0.80 \pm 1.07^{\mathrm{b}}$ & $-2.83 \pm 1.42^{\mathrm{b}}$ \\
\hline
\end{tabular}

${ }^{\mathrm{a}, \mathrm{b}}$ values in columns with different superscript letters are significantly different by the Tukey test $(\mathrm{p}<0.05)$.

Our results suggest an association between polymorphism in the mitochondrial $t R N A^{a s n}$ gene with growth traits in $B$. indicus Nelore cattle. The differences for maternal and direct weight estimated breeding values were not caused by a $B$. taurus nuclear genome effect since this sample were known to harbor the $B$. indicus mtDNA and were progeny of registered POI sires and cows.

There are reports associating cytoplasmic lineage and growth and milk traits effects in various cattle breeds. Tess et al. (1987) reported that cytoplasmic effects influenced pre-weaning and milk traits in Hereford cattle but later results did not confirm this effect (Tess and Robison, 1990), while Schutz et al., (1993) found that maternal lineage was responsible for $4 \%$ to $15 \%$ of the phenotypic variation in milk traits of Holstein-Friesian cattle. Boettcher et al., (1996b) reported that the inclusion of the maternal lineage effect in a simulated animal model gave better estimations of heritability and permanent environment variance and also accurate estimated breeding values. However, due to small number of different lineages in our data set we could not test if cytoplasmic lineage was associated with breeding value variation.

Table 4 - Analysis of variance between scrotal circumference (SC, in centimeters) estimated breeding values for the $\mathrm{G} 5501 \rightarrow \mathrm{T}(\mathrm{G}, \mathrm{n}=247$; , $\mathrm{n}=71$ ) mitochondrial $t R N A^{a s n}$ single nucleotide polymorphism (SNP). The table shows degrees of freedom (DF) and the mean square SC estimated breeding values at 365,455 and 550 days.

\begin{tabular}{lrccc}
\hline & & \multicolumn{3}{c}{$\begin{array}{l}\text { Scrotal circumference estimated } \\
\text { breeding values (mean squares) }\end{array}$} \\
\cline { 3 - 5 } Source & $\mathrm{DF}$ & $\mathrm{SC}_{365}$ & $\mathrm{SC}_{455}$ & $\mathrm{SC}_{550}$ \\
\hline Genotype & 1 & 0.00 & 0.05 & 0.06 \\
Error & 343 & 0.22 & 0.56 & 0.51 \\
$\mathrm{P}>\mathrm{F}$ & & 0.97 & 0.75 & 0.72 \\
\hline
\end{tabular}

Quantitative traits have also been associated with mtDNA polymorphisms. D-loop variation has been associated to carcass traits such as longissimus muscle area and beef marbling score (Mannen et al., 1998), milk production as measured by yield, fat content and estimated milk energy (Schutz et al., 1994), and calving rates (Sutarno et al., 2002). Furthermore, polymorphic sites on rRNA genes have also been associated with milk traits (Boettcher et al., 1996a).

The effect of variation in the mitochondrial genome on milk and beef traits is thought to be a consequence of changes in metabolic rate or the energy available for milk production and muscle development, the differences reported by us in this study tend to support this hypothesis.

We investigated scrotal circumference (SC) because this has been correlated with reproductive traits in Nelore cattle (Martins-Filho and Lôbo, 1991) and the heritability of scrotal circumference is considered moderate to high at 0.36 to 0.47 (Garnero et al., 2001; Pereira et al., 2002; Silveira et al., 2004). However, no studies have suggested that the mitochondrial genome may influence fertility traits

Table 5 - Scrotal circumference (SC, in centimeters) estimated breeding values for the $\mathrm{G} 5501 \rightarrow \mathrm{T}(\mathrm{G}, \mathrm{n}=247 ; \mathrm{T}, \mathrm{n}=71)$ mitochondrial $t R N A^{\text {asn }}$ single nucleotide polymorphism (SNP). The table shows the means and standard errors of the mean (SE) for SC estimated breeding values at 365, 450 and 550 days.

\begin{tabular}{lccc}
\hline & \multicolumn{3}{c}{$\begin{array}{c}\text { Scrotal circumference estimated breeding values } \\
\text { (means } \pm \text { standard errors, cm) }\end{array}$} \\
\cline { 2 - 4 }$t R N A^{a s n}$ & $\mathrm{SC}_{365}$ & $\mathrm{SC}_{450}$ & $\mathrm{SC}_{550}$ \\
\hline $\mathrm{G}$ & $-0.17 \pm 0.03^{\mathrm{a}}$ & $-0.28 \pm 0.04^{\mathrm{a}}$ & $-0.31 \pm 0.04^{\mathrm{a}}$ \\
$\mathrm{T}$ & $-0.17 \pm 0.05^{\mathrm{a}}$ & $-0.31 \pm 0.08^{\mathrm{a}}$ & $-0.34 \pm 0.07^{\mathrm{a}}$ \\
\hline
\end{tabular}

avalues in columns with the same superscript letter do not differ statistically by the Tukey test $(\mathrm{p}>0.05)$. 
and the polymorphism tested by us was not associated with scrotal circumference estimated breeding values.

In humans, there are approximately 108 disorders that are associated with SNPs of mitochondrial tRNA genes. Three of these disorders involve the $t R N A^{a s n}$ gene (Brandon et al., 2005), indicating that SNPs of mitochondrial tRNA genes have an important role in mitochondria. Mitochondrial $t R N A^{a s n}$ gene SNP $(\mathrm{G} 5501 \rightarrow \mathrm{T})$ could affect maternal and direct weight estimated breeding values due to a direct effect on the functional efficiency of the $t R N A^{a s n}$ gene. Otherwise, the $t R N A^{a s n}$ gene SNP genotyped in our study may be associated to other functional polymorphisms or a group of polymorphisms (haplotype). While our results are not conclusive concerning the effect of the $t R N A^{a s n}$ gene SNP on Nelore estimated breeding values, they provide important evidence that nucleotide variation within the mitochondrial genome should be considered as genetic markers for the assisted selection of quantitative traits.

The $B$. taurus and $B$. indicus mitochondrial genomes have been completely sequenced but the existing polymorphisms between these two breeds need to be studied to further characterize the existing genetic variability in these breeds and elucidate the effects of such polymorphisms on production traits. The association of weight estimated breeding values with a $t R N A^{a s n}$ gene SNP confirms that mitochondrial DNA is a source of genetic variation that influences growth during the bovine pre-weaning and postweaning periods.

\section{Acknowledgments}

The authors would like to thank the Brazilian agencies CAPES, CNPq-PRONEX and FAPESP (proc.: 98/16573-8) for financial support and also the Breeders belonging to the Nelore Cattle Breeding Program - USP for providing blood samples from the cattle used in this study.

\section{References}

Anderson S, Bruijn MHL, Coulson AR, Eperon IC, Sanger F and Young IG (1982) Complete sequence of bovine mitochondrial DNA: Conserved features of the mammalian mitochondrial genome. J Mol Biol 156:683-717.

Attardi G (1985) Animal mitochondrial DNA: An extreme example of genetic economy. Int Rev Cytol 93:93-145.

Bell BR, McDaniel BT and Robison OW (1985) Effects of cytoplasmic inheritance on production traits of dairy cattle. $\mathrm{J}$ Dairy Sci 68:2038-2051.

Birch-Machin MA (2006) The role of mitochondria in ageing and carcinogenesis. Clin Exp Dermatol 31:548-552.

Birky CW (2001) The inheritance of genes in mitochondria and chloroplasts: Laws, mechanisms, and models. Annu Rev Genet 35:125-148.

Boettcher PJ, Freeman AE, Johnston SD, Smith RK, Beitz DC and McDaniel BT (1996a) Relationships between polymorphism for mitochondrial deoxyribonucleic acid and yield traits of Holstein cows. J Dairy Sci 79:647-654.
Boettcher PJ, Kuhn MT and Freeman AE (1996b) Impacts of cytoplasmic inheritance on genetic evaluations. J Dairy Sci 79:663-675.

Boldman K, Van Vleck L, Kriese L and Kachman S (1995) MTDFREML: User's Guide. Departament of Agriculture/Agricultural Research Service, Lincon.

Brandon MC, Lot MT, Nguyen KC, Spolim S, Navathe SB, Baldi P and Wallace DC (2005) MITOMAP: A human mitochondrial genome database-2004 update. Nucleic Acids Res 33:D611-613.

Garnero AV, Lôbo RB, Bezzerra LAF and Oliveira HN (2001) Comparação de alguns critérios de seleção para crescimento na raça nelore. Rev Bras Zootec 30:714-718. Abstract in English.

Gibson JP, Freeman AE and Boettcher PJ (1997) Cytoplasmic and mitochondrial inheritance of economic traits in cattle. Livest Prod Sci 47:115-124.

Gunski RJ, Bezzerra LAF, Meirelles FV and Lôbo RB (2001) Efeito do DNA mitocondrial sobre características de crescimento pré-desmama na raça Nelore. In: Anais da $38^{\mathrm{a}}$ Reunião Anual da Sociedade Brasileira de Zootecnia, Piracicaba, pp 23-26. Abstract in English.

Mannen H, Kojima T, Oyama K, Mukai F, Ishida T and Tsuji, S (1998) Effect of mitochondrial DNA variation on carcass traits of Japanese Black cattle. J Anim Sci 76:36-41.

Mannen H, Morimoto ML, Oyamat K, Mukai F and Tsuji S (2003) Identification of mitochondrial DNA substitutions related to meat quality in Japanese Black cattle. J Anim Sci 81:68-73.

Martins-Filho R and Lôbo RB (1991) Circunferência escrotal como critério de seleção em bovinos tendo em vista o melhoramento de características reprodutivas em ambos os sexos. Ciênc Animal 1:83-91. Abstract in English.

Meirelles FV, Rosa AJM, Lôbo RB, Garcia JM, Smith LC and Duarte FM (1999) Is the American Zebu really Bos indicus? Genet Mol Biol 22:543-546.

Northcutt SL, Willham RL and Wilson DE (1991) Genetic parameters for nuclear and non-nuclear inheritance in three synthetic lines of beef cattle differing in mature size. J Anim Sci 69:4745-4753.

Pegoraro L, Yang Z, Samake S, Meirelles FV, Bordingnon V, Moquin LC and Smith LC (1996) Sequence comparison of mitochondrial tRNA genes and origin of light strand replication in Bos taurus and Nelore (Bos indicus) breeds. Anim Genet 27:91-94.

Pereira E, Eler JP and Ferraz JP (2002) Análise genética de características reprodutivas na raça Nelore. Pesq Agropec Bras 37:703-708. Abstract in English.

Quintanilla R, Varona L, Pujol MR and Piedrafita J (1999) Maternal animal model with correlation between maternal environmental effects of related dams. J Anim Sci 77:29042917.

Ron M, Yoffe O and Weller JI (1993) Sequence variation in D-loop mtDNA of cow lineages selected for high and low maternal effects on milk production. Anim Genet 24:183186.

Sambrook J, Fritch EF and Maniatis T (2001) Molecular Cloning: A Laboratory Manual. 3 edition. Cold Spring Harbor Laboratory Press, New York.

SAS Institute Inc. (2001) Statistical Analysis Software. 8.2 edition. SAS Institute Inc., Cary. 
Schutz MM, Freeman AE, Beitz DC and Mayfield JE (1992) The importance of maternal lineage on milk yield traits of dairy cattle. J Dairy Sci 75:1331-1341.

Schutz MM, Freeman AE, Lindberg GL and Beitz DC (1993) Effects of maternal lineages grouped by mitochondrial genotypes on milk yield and composition. J Dairy Sci 76:621629.

Schutz MM, Freeman AE, Lindberg GL, Koehler CM and Beitz DC (1994) The effect of mitochondrial DNA on milk production and health of dairy cattle. Livestock Production Science 37:283-295.

Silveira JC, McManus C, Mascioli AS, Silva LOC, Silveira AC, Garcia JAS and Louvandini H (2004) Study of genetic and environmental factors on production and reproduction traits in a Nelore herd in Mato Grosso do Sul state. Rev Bras Zootec 33:1432-1444.

Smith LC and Alcivar AA (1993) Cytoplasmic inheritance and its effects on development and performance. J Reprod Fertil Suppl 48:31-43.

Smith LC, Bordignon V, Garcia JM and Meirelles FV (2000) Mitochondrial genotype segregation and effects during mammalian development: Applications to biotechnology. Theriogenology 53:35-46.

Sutarno CG, Cummins JM, Greeff J and Lymbery AJ (2002) Mitochondrial DNA polymorphisms and fertility in beef cattle. Theriogenology 57:1603-1610.
Suzuki R, Kemp SJ and Teale AJ (1993) Polymerase chain reaction analysis of mitochondrial DNA polymorphism in N'Dama and Zebu cattle. Anim Genet 24:339-343.

Taanman JW (1999) The mitochondrial genome: Structure, transcription, translation and replication. Biochim Biophys Acta 1410:103-123.

Tess MW and MacNeil MD (1994) Evaluation of cytoplasmic genetic effects in Miles City Line 1 Hereford cattle. J Anim Sci 72:851-856.

Tess MW, Reodecha C and Robison OW (1987) Cytoplasmic genetic effects on preweaning growth and milk yield in Hereford cattle. J Anim Sci 65:675-684.

Tess MW and Robison OW (1990) Evaluation of cytoplasmic genetic effects in beef cattle using an animal model. J Anim Sci 68:1899-1909.

Wagner RP (1972) The role of maternal effects in animal breeding II: Mitochondria and animal inheritance. J Anim Sci 35:1280-1287.

\section{Internet Resource}

Nelore cattle breeding program (NCBP) at the University of São Paulo, under the auspices of the Brazilian National Association of Breeders and Researchers of Nelore Cattle Associação Nacional de Criadores e Pesquisadores - ANCP) http://www.ancp.org.br/sumarios.

Associate Editor: Luiz Lehmann Coutinho 